\title{
Anthropometry for WorldSID A World-Harmonized Midsize Male Side Impact Crash Dummy
}

S. Moss, Z. Wang and M. Salloum

First Technology Safety Systems

M. Reed

University of Michigan Transportation Research Institute

M. van Ratingen

TNO

\author{
D. Cesari, R. Scherer and T. Uchimura \\ WorldSID Task Group Chairpersons
}

M. Beusenberg WorldSID Program Manager

Permission is hereby granted for a copyright release fee of $\$ 300$ per paper. An invoice will follow under separate cover. Please be sure to include the following credit statement with these papers:

"(C) Society of Automotive Engineers, Inc. The following papers are published on this web-site with permission from the Society of Automotive Engineers, Inc. As a user of this web-site, you are permitted to view these papers on-line, download the PDF file and to print a copy at no cost for your use only. Dowloaded PDF files and printouts of SAE papers contained on this web-site may not be copied or distributed to others or for the use of others." 
The appearance of this ISSN code at the bottom of this page indicates SAE's consent that copies of the paper may be made for personal or internal use of specific clients. This consent is given on the condition, however, that the copier pay a $\$ 7.00$ per article copy fee through the Copyright Clearance Center, Inc. Operations Center, 222 Rosewood Drive, Danvers, MA 01923 for copying beyond that permitted by Sections 107 or 108 of the U.S. Copyright Law. This consent does not extend to other kinds of copying such as copying for general distribution, for advertising or promotional purposes, for creating new collective works, or for resale.

SAE routinely stocks printed papers for a period of three years following date of publication. Direct your orders to SAE Customer Sales and Satisfaction Department.

Quantity reprint rates can be obtained from the Customer Sales and Satisfaction Department.

To request permission to reprint a technical paper or permission to use copyrighted SAE publications in other works, contact the SAE Publications Group.

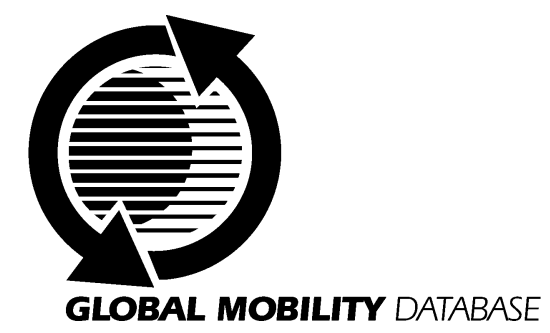

All SAE papers, standards, and selected books are abstracted and indexed in the Global Mobility Database

No part of this publication may be reproduced in any form, in an electronic retrieval system or otherwise, without the prior written permission of the publisher.

ISSN 0148-7191

Copyright $\odot 2000$ Society of Automotive Engineers, Inc.

Positions and opinions advanced in this paper are those of the author(s) and not necessarily those of SAE. The author is solely responsible for the content of the paper. A process is available by which discussions will be printed with the paper if it is published in SAE Transactions. For permission to publish this paper in full or in part, contact the SAE Publications Group.

Persons wishing to submit papers to be considered for presentation or publication through SAE should send the manuscript or a 300 word abstract of a proposed manuscript to: Secretary, Engineering Meetings Board, SAE.

\section{Printed in USA}




\title{
Anthropometry for WorldSID A World-Harmonized Midsize Male Side Impact Crash Dummy
}

\author{
S. Moss, Z. Wang and M. Salloum \\ First Technology Safety Systems
}

M. Reed
University of Michigan Transportation Research Institute

M. van Ratingen

TNO

D. Cesari, R. Scherer and T. Uchimura

WorldSID Task Group Chairpersons

M. Beusenberg

WorldSID Program Manager

Copyright @ 2000 Society of Automotive Engineers, Inc.

\begin{abstract}
The WorldSID project is a global effort to design a new generation side impact crash test dummy under the direction of the International Organization for Standardization (ISO). The first WorldSID crash dummy will represent a world-harmonized mid-size adult male. This paper discusses the research and rationale undertaken to define the anthropometry of a world standard midsize male in the typical automotive seated posture. Various anthropometry databases are compared region by region and in terms of the key dimensions needed for crash dummy design. The Anthropometry for Motor Vehicle Occupants (AMVO) dataset, as established by the University of Michigan Transportation Research Institute (UMTRI), is selected as the basis for the WorldSID mid-size male, updated to include revisions to the pelvis bone location. The proposed mass of the dummy is $77.3 \mathrm{~kg}$ with full arms. The rationale for the selected mass is discussed. The joint location and surface landmark database is appended to this paper.
\end{abstract}

\section{INTRODUCTION}

The Anthropomorphic Test Devices Working Group of the International Organization for Standardization (ISO), (ISO/TC22/SC12/WG5) initiated the WorldSID project to develop a single, worldwide harmonized, mid-sized male side impact crash test dummy to replace the existing regulatory and research side impact dummies. The ISO goal is to have a single side impact dummy with improved biofidelity and worldwide acceptance for both regulatory and research use. A Task Group has been formed to lead the development of this new dummy consisting of members from the Americas, Asia/Pacific and European regions.

A number of federal governments worldwide, including the U.S., Canada, the European Union, Australia and Japan, have joined forces under a cooperative agreement named the International Harmonization Research Activities (IHRA) to conduct crash test and biomechanics research. The results of these activities are intended to form the basis for future harmonized standards. One of the ad hoc assignments of the IHRA Biomechanics group was to review the available anthropometric data for the purpose of specifying the anthropometry for WorldSID [1]. IHRA-Biomechanics determined the design will require:

- Some combination of world anthropometric data to facilitate the representation of international populations.

- Sufficient anthropometric definition to allow the specification of WorldSID.

- Anthropometric design specifications that accommodate current secular trend and projected trends. 
IHRA-Biomechanics used the 1990 report, "International Data on Anthropometry" by Jürgens et al [2]. Jürgens divided the world population into twenty regions for which certain body measurements were available in the 25 to 45 year old age group. For each of these regions, nineteen ergonomically important body measurements were compiled for both genders for the 5th, 50th and 95th percentiles. The Jürgens data was corrected for the effects of secular growth projected to the year 2000.

IHRA-Biomechanics entered the nineteen body measurements (Table $A 3$ ) reported by Jürgens for the twenty regions of the world into a database and analyzed the data in five ways:

1. Un-weighted worldwide mean.

2. Worldwide mean weighted by population in each region.

3. Un-weighted mean of regions containing Organization for Economic Cooperation and Development (OECD) countries.

4. Mean weighted by population for each region containing OECD countries.

5. Mean weighted by fatality rate for the OECD country in that region.

IHRA determined Methods 1 and 2 tend to bias the data towards a smaller anthropometry because of the large populations in China, SE Asia and South America who are smaller in stature, but do not necessarily represent a dominant portion of the population of vehicle occupants likely to be fatally injured. IHRA applied weighting methods 3 to 5 to develop an anthropometry for those OECD countries that have a quantifiable road trauma problem. This data was then compared to the adult Hybrid III crash dummy family with the following comments:

- Methods 1 and 2 yield dimensions that are smaller than the current Hybrid III family.

- Methods 3 and 4 yield dimensions that are larger than the current Hybrid III family, particularly the 95th male.

- Method 5 yields dimensions that are similar for the 50th male, but larger for the 5th female and 95th male than the current Hybrid III family.

IHRA concluded that the anthropometry projected by Method 5 would be most appropriate for WorldSID. This paper compares this anthropometry dataset with other sources to produce a detailed dataset for WorldSID.

\section{ANTHROPOMETRY DATABASES}

Crash test dummy design requires significantly more detailed anthropometry specifications than typically available in general anthropometry studies. The dummy requires internal joint center locations, segment masses, segment center of gravity locations, inertial properties and an external flesh surface. The dummy must also simulate the human in the typical semi-reclined automotive seated posture. There are two sources containing this enhanced anthropometry:

- Anthropometry of Motor Vehicle Occupants (AMVO) [3].

- RAMSIS - Rechnergestiitztes AnthropologischMathematisches System zur Insassen - Computer supported anthropological mathematical system for passenger simulation [4].

The AMVO project is a definitive study undertaken by the University of Michigan Transportation Research Institute (UMTRI) to develop specifications specifically for crash test dummies. AMVO measured surface landmarks of 25 adults and calculated the internal joint locations and segment masses and created a dataset of 147 points defining the surface landmarks, joint centers, segment origins and segment centers of gravity (Figure 2). It was published in 1985. UMTRI also developed the full sized clay models of the 5th, 50th and 95th percentiles that were subsequently molded into fiberglass shells and then scanned and surfaced for use with CAD systems (Figure 1).

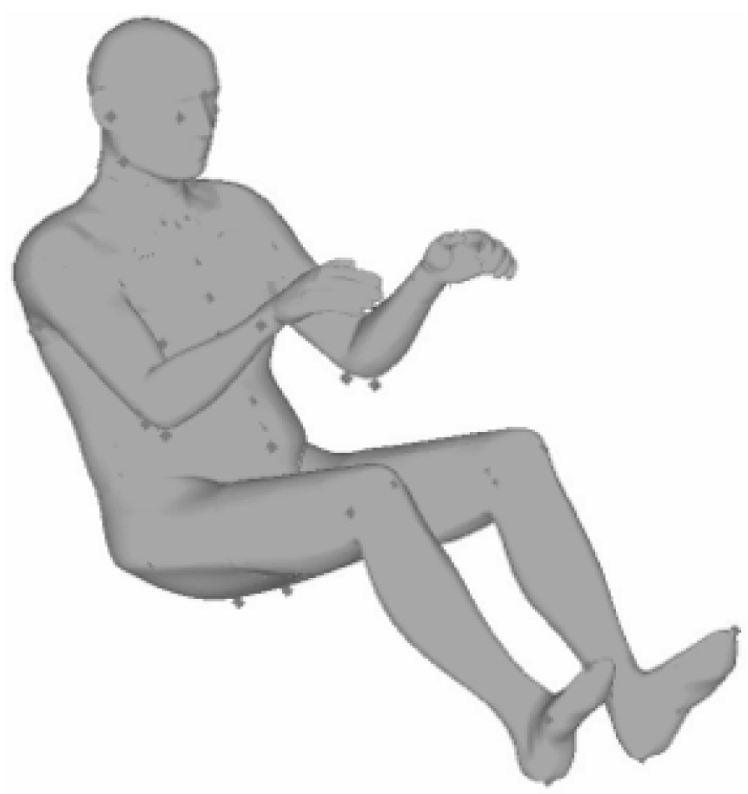

Figure 1. AMVO Surface Shell CAD Model

RAMSIS is a 3D-CAD-Ergonomics software tool developed by Tecmath $A G$ in cooperation with the German automotive industry. The RAMSIS software predicts human internal and external anthropometry based on the input of three anthropometry parameters:

- Sitting height

- Stature (standing height)

- Waist Circumference 


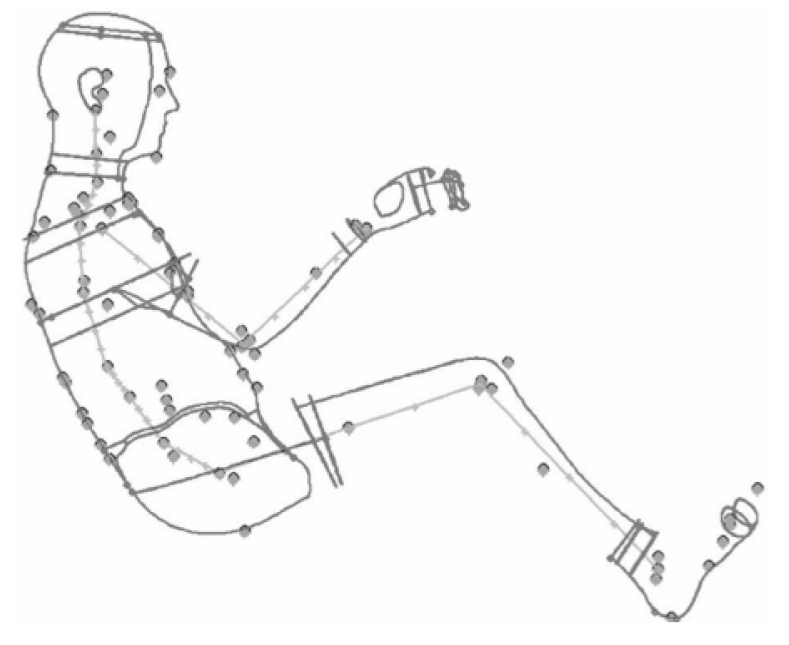

Figure 2. AMVO Point Dataset

The parameters can be entered in absolute terms or as population percentiles. Additionally, the posture can be defined as standing or seated, or in the semi-reclined, automotive seated posture. The anthropometry is further refined by groupings according to age, secular growth and gender, and the reference anthropometry database can be chosen from several sources, either individually or combined. These sources are:

- Germany (formerly East Germany)

- US and Canada (Hanes 1979)

- Japan and Korea (HQL)

- US updated (Hanes 1997, proprietary)

- Japan updated (HQL 1997, proprietary)

RAMSIS outputs internal joint coordinates for the selected size and posture, together with body segmentations, masses, C.G. locations and moments of inertia. It also creates a faceted surface model for import to CAD systems.

\section{COMPARISON OF ANTHROPOMETRY DATABASES}

Table 1 compares the statures (standing height), seated heights and weight for the IHRA proposal, the AMVO dataset and the five databases from the RAMSIS software [5]. The deviation from the IHRA proposal is shown in parentheses.

Excluding the Japan and Korea studies, the predicted statures are very similar, with a maximum deviation of $17 \mathrm{~mm}$ for the East German study. The AMVO mid-size male is $1 \mathrm{~mm}$ smaller than the IHRA proposal. The seated heights for all the databases, including the Japan and Korea studies, are within $10 \mathrm{~mm}$. This implies the major anthropometrical difference between the Asian and Western populations is in the leg length.

Since there is very little difference between the studies, and the AMVO data contains all segment lengths, the AMVO stature of $1753 \mathrm{~mm}$ is adopted for WorldSID.
Table 1. Comparison of Anthropometry Studies for the Mid-Size Male ( ${ }^{*}$ Proprietary anthropometry studies)

\begin{tabular}{|l|c|c|c|}
\hline Study & $\begin{array}{c}\text { Stature } \\
(\mathbf{m m})\end{array}$ & $\begin{array}{c}\text { Seated } \\
\text { Height } \\
(\mathbf{m m})\end{array}$ & $\begin{array}{c}\text { Weight } \\
(\mathbf{k g})\end{array}$ \\
\hline IHRA (Jurgens) & 1754 & 921 & \\
\hline AMVO & $\begin{array}{c}1753 \\
(-1)\end{array}$ & $\begin{array}{c}911 \\
(-10)\end{array}$ & 76.7 \\
\hline RAMSIS German & $\begin{array}{c}1771 \\
(+17)\end{array}$ & $\begin{array}{c}931 \\
(+10)\end{array}$ & 79.2 \\
\hline RAMSIS Japan * & $\begin{array}{c}1689 \\
(-65)\end{array}$ & $\begin{array}{c}911 \\
(-10)\end{array}$ & 64.8 \\
\hline RAMSIS USA * & 1765 & 923 & 82.0 \\
& $(+6)$ & $(+2)$ & \\
\hline RAMSIS & 1755 & 917 & 72.7 \\
US/Canada & $(+1)$ & $(-4)$ & \\
\hline RAMSIS & 1695 & 921 & 66.6 \\
Japan/Korea & $(-59)$ & $(0)$ & \\
\hline
\end{tabular}

WEIGHT - The IHRA data, based on the Jurgens study, does not include a mass proposal for the mid-size male. The average weight for the four Western databases in Table 1 is $77.6 \mathrm{~kg}$.

Masses predicted by RAMSIS show large variations, and in particular the two US studies vary from $72.7 \mathrm{~kg}$ to $82.0 \mathrm{~kg}$. The RAMSIS software predicts anthropometry based on three parameters - stature, seated height and waist circumference, which can be classified as a measure of corpulence. Variations in the waist circumference could account for large variations in the predicted mass whereas the stature shows very little variation.

The AMVO study used the 1974 NHANES II data to establish the target body weight for the midsize male ATD. The median male weight in NHANES II is $77.3 \mathrm{~kg}$. The 25 men who were measured in Phase 3 of AMVO to determine the final specifications averaged $76.7 \mathrm{~kg}$, which became the defined weight for the AMVO midsize male. The AMVO segment mass values were obtained by using the McConville regression equations to predict the segment volumes, calculating segment mass by assuming a density of $1 \mathrm{gm} / \mathrm{cm}^{3}$, and linearly scaling the resulting values so that the sum of the segment masses equaled the average body mass of the measured subjects. However it is argued the segment mass estimates should have been scaled to the target mass of $77.3 \mathrm{~kg}$ rather than the averaged measured mass of $76.7 \mathrm{~kg}$.

Since the AMVO target mass is closer to the average database mass, and less than $1 \%$ different to the AMVO measured weight, the recommended body weight of the WorldSID with full arms is $77.3 \mathrm{~kg}$. Segment masses should be scaled by 77.3/76.7. 


\section{UPDATE TO AMVO STUDY}

The Society of Automotive Engineers (SAE) Cooperative Research Program ASPECT - (Automotive Seat and Package Evaluation and Comparison Tools) has developed the next generation of seating manikin. This study identified some inaccuracies in the original AMVO dataset with respect to the location of the pelvis bone relative to the surface shell and the upper torso. Essentially the anterior superior iliac spine (ASIS) was out of position and there was too much flesh under the pelvis bone.

The pelvis bone should be located approximately $10.4 \mathrm{~mm}$ lower and $2.0 \mathrm{~mm}$ forward than originally specified. Extending the lower lumbar spine by this amount accommodates this offset.

RE-POSITIONING PROCEDURE - UMTRI has defined a re-positioning procedure to update the original AMVO dataset.

\section{Alignment of Surface Shell}

1. Use surface landmarks at L5 (point 12) and T8 (point 9) to set the shell model recline angle as drawing MM-101 (24.6 deg).

2. Set $Z$ coordinate of posterior calcaneus (point 92) to the AMVO drawing MM-101.

3. Set $X$ coordinate of Glabbela (point 1) to the AMVO drawing MM-101.

4. Check the points in the lumbar/torso area to confirm the model position, adjusting $X$ by $3 \mathrm{~mm}$.

\section{Relocation of $\mathrm{H}$-Point}

1. Locate the mid-point between the two ASIS points and translate to $0,0,0$.

2. Enter following reference coordinates:

\begin{tabular}{|l|r|r|r|}
\hline Location & $X(\mathrm{~mm})$ & $\mathrm{Y}(\mathrm{mm})$ & $\mathrm{Z}(\mathrm{mm})$ \\
\hline L5 & -150 & 2 & -72 \\
\hline L5 S1 Joint & -687 & 0 & -43 \\
\hline Right Hip Joint & 23 & -835 & -934 \\
\hline Left Hip Joint & 23 & 835 & 934 \\
\hline
\end{tabular}

3. Translate the model so that mid $\mathrm{H}$-point is $0,0,0$.

4. Move L5/S1 (point 60) to $(-89,0,39)$.

5. Reposition L2/L3 (point 59) so that it is located $60 \%$ of the distance from L5/S1 (point 60) to T12/L1 (point $58)$.

The translation vector from the mid-point of the old $\mathrm{H}$-point to that of the new $\mathrm{H}$-point is:

$$
\mathrm{H}(\text { new })=\mathrm{H}(\text { old })+\mathrm{dH}
$$

where: $d H=2 i+10.4 k,(x=i, y=j, z=k)$

\section{COMPARISON OF AMVO AND RAMSIS MODELS}

The two datasets and surface files were merged into one $C A D$ file and translated so that files have common $\mathrm{H}$-point at 0,0,0 (Figure 3).

Figure 3 illustrates the initial positioning of the two datasets and they exhibit a very similar profile. There is a discrepancy at the back centerline and the back of the head. The foot angles are different and the arm positions, but this can be corrected by re-posturing.

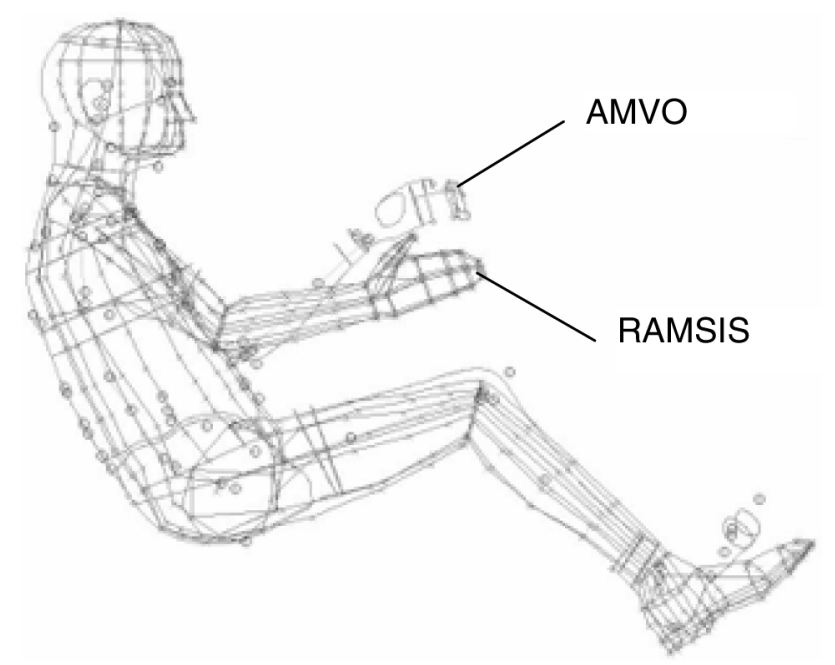

Figure 3. AMVO and RAMSIS Datasets Overlay

The RAMSIS model was rotated rearward by 2.5 degrees about the $\mathrm{H}$-point. The overlay is shown in Figure 4. The two datasets now match very closely.

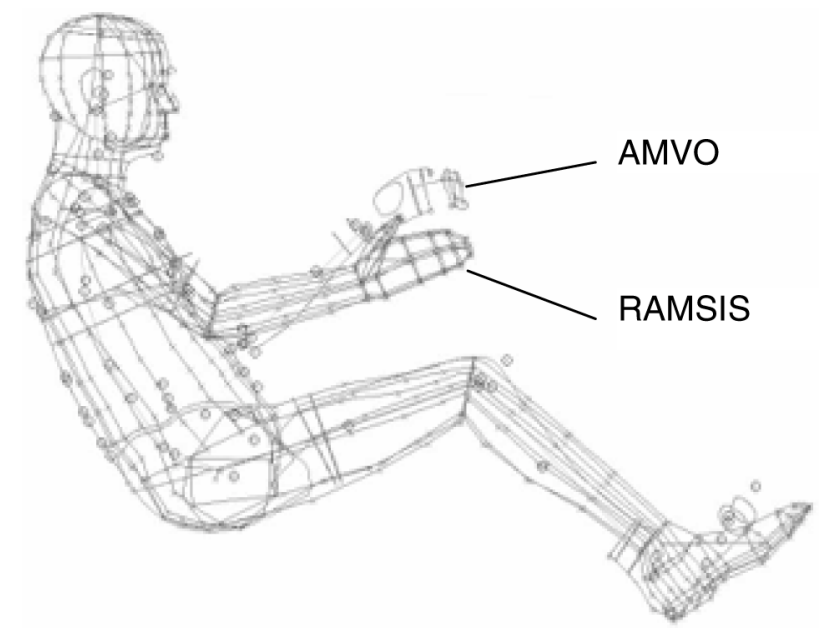

Figure 4. AMVO and RAMSIS Overlay - RAMSIS rotated rearward 2.5 degrees

Figure 5 shows the datasets overlaid with the surface landmarks and the surface shells hidden, leaving just the internal joint coordinates. This is known as the 'Stickman'. The RAMSIS data exhibits increased spine lordosis, and a shorter upper arm segment. 


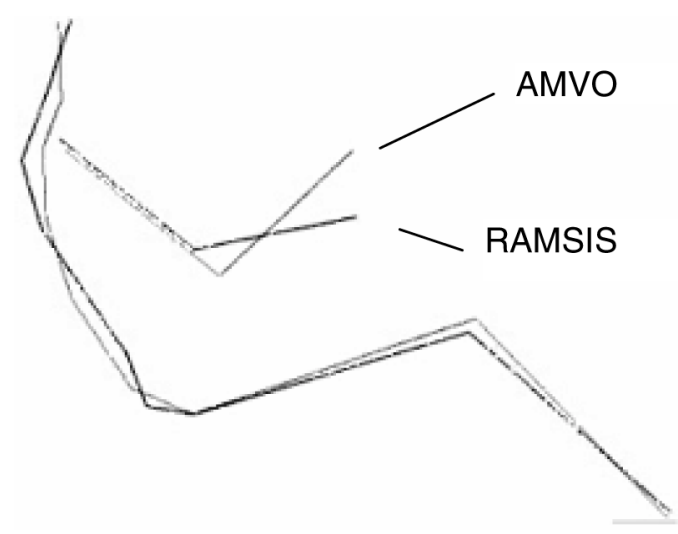

Figure 5. AMVO and RAMSIS Stickman

ARM SEGMENT LENGTH - The AMVO upper arm segment length is $295.6 \mathrm{~mm}$ and the RAMSIS is $256.4 \mathrm{~mm}$, a difference of $39.2 \mathrm{~mm}$. This is a significant difference and further study was necessary.

Table 2 compares values of arm and forearm segment lengths obtained from several different studies. The primary source for comparison is the AMVO study [3]. The AMVO values are compared to a simple scaling from Drillis and Contini [6] and two sets of values derived from Webb Associates [7].

Table 2. Comparison of Arm Segment Lengths for Men $1753 \mathrm{~mm}$ Tall

\begin{tabular}{|l|r|r|}
\hline Study & $\begin{array}{c}\text { Arm } \\
\text { Length } \\
(\mathrm{mm})\end{array}$ & $\begin{array}{c}\text { Forearm } \\
\text { Length } \\
(\mathrm{mm})\end{array}$ \\
\hline Schneider et al. AMVO $^{1}$ & 296 & 276 \\
\hline Drillis and Contini $^{2}$ & 326 & 256 \\
\hline Webb Associates (50\%male) $^{3}$ & 304 & 273 \\
\hline Webb Associates Length Calcs $^{4}$ & 298 & 258 \\
\hline
\end{tabular}

1. Schneider et al. (1985) [3].

2. Drillis and Contini [6] scaled from stature.

3. Webb Associates [7] reported median male values.

4. Calculated values for reference stature $(1.753 \mathrm{~m})$ using Webb Associates methods [7], which reference Trotter and Gleser [8] and Dempster [9].

One important question in assessing the validity of the AMVO study [3] is whether the 25 men who were measured had appropriate upper extremity segment lengths. Table 3 shows the values of three standard anthropometric measures compared to those obtained from the Anthropometric Survey of U.S. Army Personnel (ANSUR) [10] using linear regressions on stature. The AMVO exterior dimensions are very close to the values expected for males $1753 \mathrm{~mm}$ tall. Notably, shoulder-elbow length and radiale-stylion length are within $3 \mathrm{~mm}$ of the values predicted from ANSUR.

Table 3. Comparison of AMVO and ANSUR Derived Upper Extremity Length ( $\mathrm{mm}$ )

\begin{tabular}{|l|r|r|r|}
\hline Study & $\begin{array}{l}\text { Shoulder } \\
\text { to Elbow } \\
\text { Length }\end{array}$ & $\begin{array}{l}\text { Forearm } \\
\text { to Hand } \\
\text { Length }\end{array}$ & $\begin{array}{l}\text { Radiale } \\
\text { to Stylion } \\
\text { Length }\end{array}$ \\
\hline AMVO [3] & 365 & 474 & 269 \\
\hline ANSUR & 368 & 483 & 269 \\
\hline
\end{tabular}

The men in the AMVO study had upper extremity exterior dimensions (standard anthropometry) that closely match those expected based on the much larger ANSUR survey of U.S. Army personnel [10]. Consequently, any discrepancies in segment length between AMVO and other studies with the same size individuals are likely due to differences in the manner in which the joint locations are calculated from external landmarks.

The Webb Associates calculation methods use regression equations based on an extensive study of U.S. servicemen's remains to estimate long-bone lengths from stature [7]. Ratios developed by Dempster [9] from cadaver dissections are then used to relate the bone lengths to the functional segment lengths. For example, the humerus length for a male $1753 \mathrm{~mm}$ tall is estimated to be $333 \mathrm{~mm}$, and the arm segment length is estimated to be 89.44 percent of the humerus length, or $298 \mathrm{~mm}$.

The Webb Associates methods give a value for the arm segment length very similar to that obtained in the AMVO study. However, the forearm segment length differs by about $18 \mathrm{~mm}$. Based on the available information, the AMVO value would appear to be the more reliable, because it is based on landmark locations measured on men who are demonstrably typical in their upper extremity segment exterior dimensions for men of their stature.

Based on the foregoing analyses, the recommended arm segment lengths for WorldSID are those from the AMVO study:

- Arm Segment Length

- Forearm Segment Length

The Hybrid III 50th Dummy upper arm length is also shorter than the AMVO data, although in the 'hands-onwheel' posture with approximately 90 degrees between upper arm and forearm, the exterior surfaces of the Hybrid III arm align well with the AMVO data. The difference is caused by the location of the elbow joint. The AMVO data correctly puts the joint at the outer surface of the arm, whereas the Hybrid III elbow joint is at the center of the arm cross-section. When the Hybrid III arm is straightened, it is approximately $60 \mathrm{~mm}$ shorter than the typical midsize male. 


\section{CONCLUSIONS}

1. The 1983 AMVO study has been compared to available anthropometrical databases, and is consistent with the stature and mass predictions for a world mid-size male.

2. The AMVO study is the recommended source to define the anthropometry of the mid-size male WorldSID. The WorldSID anthropometry is defined in Appendix 2.

\section{ACKNOWLEDGMENTS}

Keith Seyer, Michelle Walker, Australia Commonwealth Department of Transport and Regional Services.

ISO WorldSID Design Team - First Technology Safety Systems, TNO, Robert A. Denton, ASTC, DTS, Biokinetics, INRETS, TRL.

ISO WorldSID Task Group.

\section{REFERENCES}

1. Keith Seyer, Australian Transport Safety Bureau, 'Anthropometry for a WorldSID Dummy', Memo: IHRA Biomechanics Group, June 7, 1999.

2. Jürgens, H.W, Aune, I.A., Pieper U., (1990). 'International Data on Anthropometry'.

3. Schneider, L.W., Robbins, D.H., Pflüg, M.A., and Snyder, R.G., (1985) 'Development of an Anthropometrically based Design Specifications for an Advanced Adult Anthropomorphic Dummy Family'. Volumes 1-3, Final Report DOT-HS-806-715. National Highway Traffic Safety Administration U.S. Department of Transportation, Washington D.C.

4. Seidl, A., 'RAMSIS - A New CAD Tool for Ergonomic
Analysis of Vehicles Developed for the German Automotive Industry'. Tecmath $\mathrm{GmbH}$, SAE Paper 970088.

5. M. Hoofman, R. Happee, M. van Ratingen, TNO. Comparison between Jurgens, UMTRI and RAMSIS Data. EEVC WG12 Memo, September 17, 1999.

6. Drillis and Contini (1966). 'Body Segment Parameters'. BP174-945. Technical Report Number 1166.03 New York University School of Engineering and Science, New York.

7. Webb Associates (1978). Anthropometric Source Book, Vol.1. National Aeronautics and Space Administration, Washington D.C.

8. Trotter, M., Gleser, G. (1958). 'A Re-Evaluation of Estimation of Stature Based on Measurements of Stature Taken During Life and of Long Bones after Death'. American Journal of Physical Anthropology, 16(1): 79-124.

9. Dempster, W.T. (1955). 'Space Requirements of the Seated Operator'. WADC-TR-55-159. Aerospace Medical Research Laboratories, Ohio.R. Happe et al. 'A Mathematical Human Body Model for Frontal and Rearward Seated Automotive Impact Loading' Stapp Paper, 98S-36, 1998.

10. Gordon, C.C., Churchill, T., Clauser, C.E., Bradtmiller, B., McConville, J.T., Tebbetts, I., Walker, R.A. (1989). 1988 Anthropometric Survey of U.S. Army Personnel: Methods and Summary Statistics. Final Report (NATICK/TR-89/027) U.S. Army Natick Research Development and Engineering Center, Natick, Massachusetts.

\section{CONTACT}

Steve Moss, Technical Director, First Technology Safety Systems, Inc. 47460 Galleon Drive, Plymouth, MI 48170, USA. www.ftss.com

\section{APPENDIX 1}

Comparison of statures and masses across different anthropometry databases.

Table A1. Summary Comparison of Anthropometry Databases (Figures in brackets denote deviation from IHRA definition) * Proprietary Anthropometry Studies

\begin{tabular}{|c|c|c|c|c|c|c|c|}
\hline \multirow[b]{2}{*}{ Body Measurement } & \multirow{2}{*}{$\begin{array}{c}\text { IHRA/ } \\
\text { Jurgens }\end{array}$} & \multirow[t]{2}{*}{ AMVO } & \multicolumn{5}{|c|}{ RAMSIS Database } \\
\hline & & & $\begin{array}{c}\text { US/ } \\
\text { Canada }\end{array}$ & US $^{*}$ & Germany & $\begin{array}{c}\text { Japan/ } \\
\text { Korea }\end{array}$ & Japan $^{*}$ \\
\hline Stature (mm) & $\begin{array}{r}1754 \\
(0)\end{array}$ & $\begin{array}{r}1753 \\
(-1)\end{array}$ & $\begin{array}{r}1755 \\
(1)\end{array}$ & $\begin{array}{r}1765 \\
(11)\end{array}$ & $\begin{array}{r}1771 \\
(17)\end{array}$ & $\begin{array}{l}1695 \\
(-59)\end{array}$ & $\begin{array}{l}1689 \\
(-65)\end{array}$ \\
\hline Sitting Height (mm) & $\begin{array}{r}921 \\
(0)\end{array}$ & $\begin{array}{r}911 \\
(-10)\end{array}$ & $\begin{array}{l}917 \\
(-4)\end{array}$ & $\begin{array}{r}923 \\
(2)\end{array}$ & $\begin{array}{l}931 \\
(10)\end{array}$ & $\begin{array}{r}921 \\
(0)\end{array}$ & $\begin{array}{r}911 \\
(-10)\end{array}$ \\
\hline Chest width (mm) & & $312^{1}$ & 296 & 313 & 308 & 300 & 311 \\
\hline Hip Breadth - sitting (mm) & 347 & $\begin{array}{l}322^{2} \\
(-25)\end{array}$ & $\begin{array}{l}339 \\
(-8)\end{array}$ & $\begin{array}{r}353 \\
(6)\end{array}$ & $\begin{array}{r}351 \\
(4)\end{array}$ & $\begin{array}{r}326 \\
(-21)\end{array}$ & $\begin{array}{l}340 \\
(-7)\end{array}$ \\
\hline Body Mass (kg) & & 76.7 & 72.7 & 82 & 79.2 & 66.6 & 64.8 \\
\hline
\end{tabular}

1. At 10 th rib

2. At iliocristale 


\section{APPENDIX 1 (CONTINUED)}

Table A2. Detailed Comparison of Anthropometry Databases. Dimensions in mm unless otherwise noted.

\begin{tabular}{|c|c|c|c|c|c|c|c|}
\hline & $\begin{array}{c}\text { IHRA/ } \\
\text { Jurgens }\end{array}$ & AMVO & & & RAMSIS & & \\
\hline Body Measurement & & & $\begin{array}{c}\text { US \& } \\
\text { Canada }\end{array}$ & US (prop) & German & $\begin{array}{c}\text { Japan \& } \\
\text { Korea }\end{array}$ & $\begin{array}{l}\text { Japan } \\
\text { (prop) }\end{array}$ \\
\hline Stature & 1754 & 1753 & 1755 & 1765 & 1771 & 1695 & 1689 \\
\hline Sitting Height & 921 & 911 & 917 & 923 & 931 & 921 & 911 \\
\hline Eye Height, sitting & 804 & & & & & & \\
\hline Forward Reach (fingertips) & 845 & & & & & & \\
\hline Shoulder breadth (bideltoid) & 447 & 449 & 462 & 482 & 478 & 457 & 448 \\
\hline Shoulder breadth (biacromial) & 388 & 395 & & & & & \\
\hline Hip Breadth (standing) & 337 & & & & & & \\
\hline Knee Height & 539 & & 549 & 548 & 546 & 499 & 533 \\
\hline Lower leg length (popliteal height) & 443 & & & & & & \\
\hline Elbow-grip length & 353 & & & & & & \\
\hline Buttock - knee length & 600 & 593 & 604 & 615 & 615 & 594 & 560 \\
\hline Buttock - heel length & 1058 & & & & & & \\
\hline Hip Breadth (sitting) & 347 & & 339 & 353 & 351 & 326 & 340 \\
\hline Hand length & 190 & & & & & & \\
\hline Hand breadth & 088 & & & & & & \\
\hline Foot length & 262 & 264 & 291 & 296 & 295 & 280 & 223 \\
\hline Head circumference & 568 & 571 & & & & & \\
\hline Head length & 191 & 197 & 219 & 223 & 224 & 223 & 235 \\
\hline Head breadth & 155 & 158 & 155 & 159 & 159 & 156 & 161 \\
\hline Head depth & & & 191 & 194 & 196 & 195 & 189 \\
\hline Neck length & & & 100 & 93 & 098 & 095 & 90 \\
\hline Upper arm length & & & 328 & 337 & 336 & 343 & 331 \\
\hline Forearm length with hand & & & 465 & 475 & 474 & 443 & 441 \\
\hline Forearm circumference & & 254 & 273 & 285 & 282 & 269 & 167 \\
\hline Chest width & & & 296 & 313 & 308 & 300 & 311 \\
\hline Chest depth & & & 212 & 234 & 226 & 221 & 206 \\
\hline Waist circumference & & 859 & 847 & 942 & 903 & 810 & 800 \\
\hline Pelvis Width & & & 299 & 313 & 309 & 287 & 284 \\
\hline Foot Height & & & 091 & 093 & 093 & 087 & 067 \\
\hline Foot width & & 96 & 105 & 108 & 108 & 103 & 096 \\
\hline Body Mass (kg) & & 76.7 & 72.7 & 082 & 79.2 & 66.6 & 64.8 \\
\hline
\end{tabular}




\section{APPENDIX 1 (CONTINUED)}

Table A3. Mean Percentiles for Male \& Female Body Measurements across 8 Regions containing OECD Countries (Weighted by Road Fatality Rates). Dimensions in mm unless otherwise noted.

\begin{tabular}{|l|r|r|r|r|r|c|}
\hline & Men & Men & Men & Women & Women & Women \\
\hline Percentile & 5th & 50th & 95th & 5th & \multicolumn{1}{c|}{ 50th } & 95th \\
\hline Stature & 1647 & 1754 & 1863 & 1534 & 1632 & 1731 \\
\hline Sitting height & 867 & 921 & 979 & 812 & 868 & 920 \\
\hline Eye height, sitting & 747 & 804 & 857 & 693 & 746 & 804 \\
\hline Forward reach (fingertips) & 792 & 845 & 901 & 735 & 789 & 841 \\
\hline Shoulder breadth (bi-deltoid) & 409 & 447 & 485 & 357 & 396 & 428 \\
\hline Shoulder breadth (bi-acromial) & 354 & 388 & 421 & 319 & 351 & 387 \\
\hline Hip breadth (standing) & 305 & 337 & 364 & 311 & 348 & 396 \\
\hline Knee height & 492 & 539 & 583 & 452 & 489 & 527 \\
\hline Lower leg length (popliteal height) & 402 & 443 & 482 & 358 & 396 & 433 \\
\hline Elbow-grip length & 322 & 353 & 389 & 298 & 326 & 361 \\
\hline Buttock-knee length & 553 & 600 & 647 & 521 & 566 & 612 \\
\hline Buttock-heel length & 977 & 1058 & 1139 & 925 & 996 & 1070 \\
\hline Hip breadth (sitting) & 309 & 347 & 382 & 317 & 365 & 420 \\
\hline Hand length & 175 & 190 & 207 & 156 & 173 & 189 \\
\hline Hand breadth & 80 & 88 & 93 & 70 & 76 & 84 \\
\hline Foot length & 242 & 262 & 283 & 218 & 239 & 261 \\
\hline Head circumference & 536 & 568 & 594 & 518 & 546 & 571 \\
\hline Head length & 179 & 191 & 202 & 167 & 179 & 191 \\
\hline Head breadth & 145 & 155 & 165 & 137 & 146 & 156 \\
\hline
\end{tabular}




\section{APPENDIX 2 - WORLDSID ANTHROPOMETRY}

\begin{tabular}{|c|c|c|c|c|}
\hline $\begin{array}{l}\text { Land- } \\
\text { mark }\end{array}$ & Description & $X(\mathrm{~mm})$ & $Y(\mathbf{m m})$ & $\mathrm{Z}(\mathrm{mm})$ \\
\hline & Head & & & \\
\hline 1 & Glabbela & -78 & 0 & 661.4 \\
\hline 2 & Infraorbitale $(\mathrm{L}, \mathrm{R})$ & -94 & \pm 34 & 630.4 \\
\hline 3 & Tragion $(\mathrm{L}, \mathrm{R})$ & -183 & \pm 83 & 624.4 \\
\hline 4 & Gonion $(\mathrm{L}, \mathrm{R})$ & $\begin{array}{l}-171 \\
\end{array}$ & \pm 70 & 554.4 \\
\hline 5 & Gnathion & -99 & 0 & 521.4 \\
\hline \multirow[t]{2}{*}{6} & Nuchale & -260 & 0 & 589.4 \\
\hline & Vertebral Column & & & \\
\hline 7 & $\mathrm{C} 7$ & -264 & 0 & 499.4 \\
\hline 8 & $\mathrm{~T} 4$ & -291 & 0 & 390.4 \\
\hline 9 & T8 & -282 & 0 & 263.4 \\
\hline 10 & $\mathrm{~T} 12$ & -244 & 0 & 156.4 \\
\hline 11 & L2 & -215 & 0 & 097.4 \\
\hline 12 & L5 & $\begin{array}{l}-172 \\
\end{array}$ & 0 & 023.4 \\
\hline 13 & Mid-Spine 10th Rib & -240 & 0 & 148.4 \\
\hline 14 & Superior Margin Scapula $(L, R)$ & -274 & \pm 79 & 413.4 \\
\hline 15 & Inferior Margin Scapula $(\mathrm{L}, \mathrm{R})$ & -294 & \pm 126 & 277.4 \\
\hline 16 & R10 Projection To Back & -207 & 0 & 81.4 \\
\hline \multirow[t]{2}{*}{17} & Iliocristale Projection To Back & -186 & 0 & 45.4 \\
\hline & Torso & & & \\
\hline 18 & Suprasternale & -137 & 0 & 445.4 \\
\hline 19 & Mesosternale & -96 & 0 & 395.4 \\
\hline 20 & Substernal & -70 & 0 & 346.4 \\
\hline 21 & Bimammary, Midline & -50 & 0 & 291.4 \\
\hline 22 & Nipple $(\mathrm{L}, \mathrm{R})$ & -50 & \pm 113 & 300.4 \\
\hline 23 & 10th Rib, Anterior, Mid-Line & 17 & 0 & 201.4 \\
\hline 24 & Umbilicus & 37 & 0 & 163.4 \\
\hline 25 & Maximum Abdominal Protrusion & 58 & 0 & 139.4 \\
\hline \multirow[t]{2}{*}{26} & 10th Rib (L,R) & -91 & \pm 156 & 143.4 \\
\hline & Pelvis & & & \\
\hline 27 & Iliocristale & -78 & \pm 161 & 103.4 \\
\hline 28 & Anterior Superior Illac Spine (L,R) & -23 & \pm 116 & 93.4 \\
\hline 29 & Pubic Symphysis & 53 & 0 & 51.4 \\
\hline 30 & Thigh/Abdominal Junction & 23 & \pm 122 & 91.4 \\
\hline 31 & Throchanterion (Skeletal Reconstruction) (L,R) & 22 & \pm 203 & -9.6 \\
\hline \multirow[t]{2}{*}{32} & H-Point & 0 & \pm 84 & 0 \\
\hline & Shoulder & & & \\
\hline 33 & Clavicale $(\mathrm{L}, \mathrm{R})$ & -143 & \pm 23 & 453.4 \\
\hline 34 & Acromio-Clavicular Artic (L,R) & -213 & \pm 182 & 453.4 \\
\hline 35 & Greater Tubercle Humerus (L,R) & -171 & \pm 218 & 431.4 \\
\hline 36 & Acromion $(\mathrm{L}, \mathrm{R})$ & -222 & \pm 203 & 429.4 \\
\hline 37 & Anterior Scye (L,R) & -095 & \pm 154 & 390.4 \\
\hline 38 & Posterior Scye $(\mathrm{L}, \mathrm{R})$ & -212 & \pm 197 & 316.4 \\
\hline
\end{tabular}


APPENDIX 2 - WORLDSID ANTHROPOMETRY (CONTINUED)

\begin{tabular}{|c|c|c|c|c|}
\hline $\begin{array}{l}\text { Land- } \\
\text { mark }\end{array}$ & Description & $X(\mathbf{m m})$ & $Y(\mathbf{m m})$ & $\mathrm{Z}(\mathrm{mm})$ \\
\hline & Arm & & & \\
\hline 39 & Lateral Humeral Epicondyle (L,R) & 34 & \pm 242 & 234.4 \\
\hline 40 & Radiale $(\mathrm{L}, \mathrm{R})$ & 48 & \pm 243 & 219.4 \\
\hline 41 & Medial Humeral Epicondyle (L,R) & 34 & \pm 173 & 209.4 \\
\hline 42 & Olecranon $(\mathrm{L}, \mathrm{R})$ & 55 & \pm 210 & 196.4 \\
\hline 43 & Ulnar Styloid (L,R) & 228 & \pm 191 & 397.4 \\
\hline \multirow[t]{2}{*}{44} & Stylion $(\mathrm{L}, \mathrm{R})$ & 213 & \pm 135 & 409.4 \\
\hline & Leg And Foot & & & \\
\hline 45 & Lateral Femoral Epicondyle (L,R) & 406 & \pm 189 & 139.4 \\
\hline 46 & Medial Femoral Epicondyle $(L, R)$ & 409 & \pm 087 & 152.4 \\
\hline 47 & Tibiale $(L, R)$ & 426 & \pm 88 & 138.4 \\
\hline 48 & Petalla $(\mathrm{L}, \mathrm{R})$ & 451 & \pm 150 & 182.4 \\
\hline 49 & Sphyrion $(\mathrm{L}, \mathrm{R})$ & 686 & \pm 61 & -138.6 \\
\hline 50 & Metatarsal-Phalangeal (I) (L,R) & 798 & \pm 84 & -75.6 \\
\hline 51 & Digit (li) $(\mathrm{L}, \mathrm{R})$ & 841 & \pm 147 & -26.6 \\
\hline 52 & Metatarsal-Phalangeal (V) (L,R) & 787 & \pm 174 & -113.6 \\
\hline \multirow[t]{2}{*}{53} & Malleolus $(\mathrm{L}, \mathrm{R})$ & 682 & \pm 126 & -174.6 \\
\hline & Joint Centers & & & \\
\hline 54 & Head/Neck & -194 & 0 & 598.4 \\
\hline 55 & $\mathrm{C} 7 / \mathrm{T} 1$ & -191 & 0 & 479.4 \\
\hline 56 & T4/T5 & -218 & 0 & 407.4 \\
\hline 57 & T8/T9 & -213 & 0 & 297.4 \\
\hline 58 & T12/L1 & -175 & 0 & 175.4 \\
\hline 59 & L2/L3 & -141 & 0 & 120.8 \\
\hline 60 & L5/S1 & -89 & 0 & 3.9 \\
\hline 61 & Sternoclavicular & -143 & \pm 43 & 443.4 \\
\hline 62 & Claviscapular & -228 & \pm 168 & 437.4 \\
\hline 63 & Glenohumeral & -184 & \pm 173 & 403.4 \\
\hline 64 & Elbow & 38 & \pm 208 & 211.4 \\
\hline 65 & Wrist & 230 & \pm 158 & 403.4 \\
\hline 66 & Hip (H-Point) = 32 & 0 & \pm 835 & 0 \\
\hline 67 & Knee & 408 & \pm 138 & 146.4 \\
\hline \multirow[t]{2}{*}{68} & Ankle & 686 & \pm 94 & -158.6 \\
\hline & Origins Of Segments & & & \\
\hline 69 & Head & -183 & 0 & 624.4 \\
\hline 70 & Neck $=7$ & -264 & 0 & 499.4 \\
\hline 71 & Thorax $=16$ & -207 & 0 & 81.4 \\
\hline 72 & Abdominal & -91 & 0 & 143.4 \\
\hline 73 & Pelvis & -23 & 0 & 93.4 \\
\hline 74 & Upper Arms = 36 & -222 & \pm 203 & 429.4 \\
\hline 75 & Lower Arms $=40$ & 48 & \pm 243 & 219.4 \\
\hline 76 & Upper Legs = 31 & 22 & \pm 203 & -9.6 \\
\hline 77 & Lower Legs $=47$ & 426 & \pm 88 & 138.4 \\
\hline 78 & Feet & 798 & \pm 126 & -85.6 \\
\hline
\end{tabular}




\section{APPENDIX 2 - WORLDSID ANTHROPOMETRY (CONTINUED)}

\begin{tabular}{|r|l|r|r|r|}
\hline $\begin{array}{l}\text { Land- } \\
\text { mark }\end{array}$ & Description & $\mathbf{X}(\mathbf{m m})$ & $\mathbf{Y}(\mathbf{m m})$ & $\mathbf{Z}(\mathbf{m m})$ \\
\hline & Est. Segment Centers Of Gravity & & & \\
\hline 79 & Head & -177 & 0 & 656.4 \\
\hline 80 & Neck & -193 & 0 & 525.4 \\
\hline 81 & Thorax & -175 & 0 & 277.4 \\
\hline 82 & Abdomen & -83 & 0 & 120.4 \\
\hline 83 & Pelvis & -72 & 0 & 27.4 \\
\hline 84 & Upper Arms & -78 & \pm 191 & 329.4 \\
\hline 85 & Lower Arms & 151 & \pm 174 & 330.4 \\
\hline 86 & Upper Legs & 202 & \pm 131 & 74.4 \\
\hline 87 & Lower Legs & 506 & \pm 125 & 5.4 \\
\hline 88 & Feet & 765 & \pm 110 & -153.6 \\
\hline & & & & \\
\hline & Hip Segmentation Plane Points & 53 & \pm 35 & 51.4 \\
\hline 89 & Pubotuberosity & -23 & \pm 116 & 93.4 \\
\hline 90 & Shifted Asis = 28 & 39 & \pm 49 & -96.6 \\
\hline 91 & Inferior Tuberosity Projection & & & \\
\hline & Heel Point On Floor Of Seating Buck & 707 & \pm 94 & -239.6 \\
\hline
\end{tabular}

